\title{
IMPACT OF SELF-EFFICACY ON RETENTION BEHAVIOR OF FRESHMAN IN UNIVERSITIES IN KARACHI
}

\author{
Nosheen Raza* \\ Kauser Parveen ${ }^{* *}$
}

\begin{abstract}
Student retention is an important concern for higher education institutions. The present study tested self-efficacy variable to examine the impact of personal ability of freshmen in their decision to stay in the institution of higher education. The data was collected from both public and private sector universities in Karachi. A survey method was used to collect the data from 645 students from public and private sector universities. The data was analyses on IBM SPSS Statistics 20. The result showed that self-efficacy have a strong influence on intention of freshmen to stay in the same university. The impact of self-efficacy was the same for both public and private sector universities. It was recommended to include self-efficacy as a factor in retention studies.
\end{abstract}

Keywords: Universities, freshmen, retention, intention, self-efficacy, drop-out

\section{Introduction}

Higher education is a service industry and retaining students and their completion of degree successfully is one of the reasons for the presence of higher educational institutions. Retention is staying in the same institute of higher education from year to year until completion of a degree. As the society becomes more knowledge and technology oriented, the importance of higher education and retention increases. ${ }^{1}$ There has been a shift in the interest of universities from just access to higher education to students' success and retention in higher education. Students' retention behavior has been important subject of research in higher education in foreign universities for past four decades. There is a cost whether or not a student chooses to continue to stay in the same university.$^{2}$ Foreign universities are focusing more on meeting the needs of the students and retention is one of the key parameters to measure satisfaction of student in the same institution. ${ }^{3}$ Student retention is not only important to attract and retain

\footnotetext{
" Nosheen Raza, Lecturer, Department of Sociology, University of Karachi

${ }^{* *}$ Kauser Parveen, Ph.D. Associate Professor, Department of Sociology, University of Karachi

${ }^{1}$ Hagedorn, Linda Serra. "How to Define Retention." College student retention formula for student success (2005): 90-105.

${ }^{2}$ Norton, J. " Retention and personal development: Assessing the role of universities in assisting students to navigate psychological demands of higher education", Journal of the Australia and New Zealand Student Services Association 35, no. 1 (2010): 55-70.

${ }^{3}$ DeShields Jr, Oscar W, Ali Kara, and Erdener Kaynak. "Determinants of Business Student Satisfaction and Retention in Higher Education: Applying Herzberg's Two-Factor Theory." International journal of educational management 19, no. 2 (2005): 128-39.
} 
students ${ }^{4}$ but also an important indicator of institutional effectiveness and quality. ${ }^{5}$ In many countries retention numbers are used to rank the universities which help students in choosing a university. The retention numbers of students gives the information on how well the students are moving through the education ladder, how long they stay or whether the retention rates need to be improved or not. For institutions, retention information is important to know how well the students succeeded in an institution or how well the institution satisfies its admitted students as compared to other institutions. Completing a degree takes more than just entering an institute of higher education. People with higher education earn more than those without a degree. They are likely to contribute to the nation more effectively, take part in community service, save more public services, and commit fewer crimes. ${ }^{6}$

\section{Research Context}

In Pakistan, only $41.5 \%$ of population above 15 years of age is literate, the lowest in South Asia, and only $10 \%$ of the population completes twelve years of schooling due to high drop-out rates, which is the highest in South Asian countries ${ }^{7}$ Students' enrolment at universities has increased in Pakistan from 0.3 million to over one million in last 10 years with 10 percent increase in female enrolment from 36 to $46 \%$ (Annual Report, Higher Education Commission, 2014-15). The government of Pakistan is making efforts towards developing higher education institutions by providing research facilities, technologies, introducing new disciplines, developing faculty and improving student services. The concept of students' experience in universities calls for more than just focusing on curricula, assessment and teaching, it does include social activities of students and efforts of university to keep students committed to the university and their goals of degree completion ${ }^{8}$ but none of the key components to assure the quality and the developed parameters of Higher Education Commission (HEC) focus on student retention. There is data available on the number of students enrolled in different levels in higher education but no official data is existing on number of students completing the graduation or post-graduation level. Universities in Pakistan either do not learn the retention rates or do not make this information public.

Students' success in terms of retention has never been tested in any of higher education institutes of Pakistan. Few researches have been carried out in Pakistan focusing on academic experience of students $9,10,11$, satisfaction of students ${ }^{12,13,14}$ and quality and financial support in higher education ${ }^{15,16,17}$.

\footnotetext{
${ }^{4}$ Zhang, Xiaoni, Vijay Raghavan, and Ben Martz. "Investigating Is Student Retention Factors." Paper presented at the Americas Conference on Information Systems (AMCIS), California, August 6th-9th 2009.

${ }_{5}^{5}$ Crosling et al. " Improving Student Retention in Higher Education, ." Australian Universities' Rivew51, no. 2 (2009)

6 Tinto, Vincent. "Student Retention and Graduation: Facing the Truth, Living with the Consequences. Occasional Paper 1." Pell Institute for the Study of Opportunity in Higher Education (2004).

${ }^{7}$ Akram, Muhammad, and Faheem Jehangir Khan. "Public Provision of Education and Government Spending in Pakistan." Pakistan Institute of Development Economics, 2007.

${ }^{8}$ Benckendorff, Pierre, Lisa Ruhanen, and Noel Scott. "Deconstructing the Student Experience: A Conceptual Framework." Journal of Hospitality and Tourism Management 16, no. 01 (2009): 84-93.

9 Naseem, Nosheen Rachel. "Structured Peer Mentoring: Enhancing Lifelong Learning in Pakistani Universities." International Perspectives on Education (2012): 335.
} 
One study in Pakistan addressed the issue of students' withdrawal in a medical university and reported withdrawal rate of $16 \%$ between 1996 and $2001 .^{18}$

Retention not only has an impact on the students and their families but also on universities, the human resource and the economy. ${ }^{19,20}$

\section{Intention and retention}

Students' intent to re-enroll at the same institution is a student's self-disclosure about their plan to maintain an active status at the institute. Student intentions indicate whether or not that student will reenroll at the same institution the next term. ${ }^{21}$ The concept of intent to re-enroll or intent to continue was introduced by Pascarella in $1983 .{ }^{22}$ and it was found to be the strongest variable $23,24,25,26$ and single most important variable of students' retention or withdrawal behavior ${ }^{27}$ Bers and Smith (1991) found intent to reenroll to be stronger in predicting the actual behavior than academic and social

${ }^{10}$ Shah, Najmus Saher. "Predicting Factors That Affect Students'academic Performance by Using Data Mining Techniques." Pakistan Business Review (2012): 631.

${ }^{11}$ Shahzadi, Erum, and Zahoor Ahmad. "A Study on Academic Performance of University Students." Recent Advances in Statistics (2011): 255

${ }^{12}$ Abbasi, Muhammad Nauman, Ali Malik, Imran Sharif Chaudhry, and Muhammad Imdadullah. "A Study on Student Satisfaction in Pakistani Universities: The Case of Bahauddin Zakariya University, Pakistan." Asian Social Science 7, No. 7 (2011): 209.

${ }^{13}$ Butt, Babar Zaheer, and Kashif U Rehman. "A Study Examining the Students Satisfaction in Higher Education." Procedia Social and Behavioral Sciences 2 (2010): 5446-50.

${ }^{14}$ Ijaz, A, SM Irfan, S Shahbaz, M Awan, and M Sabir. "An Empirical Model of Student Satisfaction: Case of Pakistani Public Sector Business Schools." Journal of Quality and Technology Management 7, No. 2 (2011): 91-114.

${ }^{15}$ Alam Malik, Shahab, Shahzad Hassan, and Muhammad Zahid Iqbal. "Measuring Students' Perceptions and Expectations in Business Schools of Pakistan." Asian Education and Development Studies 1, No. 3 (2012): 222-36.

${ }^{16}$ Fatima, Anila, and Mohamed Nasr. "Financial Aid as Support for Student Accessibility to Higher Education in Pakistan." International Review of Business Research Papers 6, no. 3 (2010): 205-18.

${ }^{17}$ Ullah, Muhammad Hamid, Muhammad Ajmal, and Fazalur Rahman. "Analysis of Quality Indicators of Higher Education in Pakistan." Ankara, Bilkent University, 2011.

${ }^{18}$ Huda, Nighat, and Sajida Agha. "Attrition in Medical College: Experience at Ziauddin Medical University in Pakistan."Education for Health 17, No. 2 (2004): 232-35.

${ }^{19}$ Carter, Deborah Faye. "Key Issues in the Persistence of Underrepresented Minority Students." New

Directions for Institutional Research 2006, No. 130 (2006): 33-46.

${ }^{20}$ Hagedorn, op.cit. 90-105.

${ }^{21}$ Pascarella, Ernest T, Paul B Duby, and Barbara K Iverson. "A Text and Reconceptualization of a Theoretical Model of College Withdrawal in a Commuter Institution Setting." Sociology of Education (1983): $88-100$.

22 Ibid.

${ }^{23}$ Bean, John P, and Barbara S Metzner. "A Conceptual Model of Nontraditional Undergraduate Student Attrition." Review of educational research 55, No. 4 (1985): 485-540.

${ }^{24}$ Bers, Trudy H, and Kerry E Smith. "Persistence of Community College Students: The Influence of Student Intent and Academic and Social Integration." Research in higher education 32, no. 5 (1991): 539-56.

${ }^{25}$ Johnson, D. R. (1991). Formulating a Conceptual Model of Nontraditional Student Attrition and Persistence in Postsecondary Vocational Education Programs.

${ }^{26}$ Mutter, Priscilla. "Tinto's Theory of Departure and Community College Student Persistence." Journal of college student development 33, No. 4 (1992): 310-18.

${ }^{27}$ Bers \& Smith, op.cit, 539-56. 
integration. ${ }^{28}$ Focus of the administrators should be on intent to continue and institutions should use it as an indicator of students' retention ${ }^{29,30}$ as it relates to students' goal.$^{31}$

\section{Self-efficacy and retention}

Importance of a psychological variable was considered in researches on retention behavior of students as a response to the diverse population of students enrolled in higher education institutions. Therefore, the concept of self-efficacy was introduced in the study on student retention. ${ }^{32}$ Albert Bandura introduced the idea of self-efficacy in social learning theory and defined self-efficacy as "beliefs in one's capabilities to organize and execute the courses of action required to produce given attainments". ${ }^{33}$ It is individuals' belief and judgments about their skills and potential to perform specific tasks. Goal-related self-efficacy increases the effort towards the goal and individuals are more likely to complete the goals. ${ }^{34}$ Students with high self-efficacy believe that they are likely to be successful in university and thus have strong goal commitment and plan to continue their enrolment. ${ }^{35}$ Numerous studies have explored self-efficacy as a factor to predict academic achievement of students. ${ }^{36}$ and retention. ${ }^{37,} 38,39,40,{ }^{41}$ Self-efficacy can directly influence the intent to retain or can affect students' institutional commitment which may lead to their decision to leave or continue at the institution. ${ }^{42}$ Weng et.al. ${ }^{43}$ and Torres and Solberg ${ }^{44}$ found a positive relationship between self-

28 Ibid.

${ }^{29}$ Arnold, Adrienne. "Retention and Persistence in Postsecondary Education: A Summation of Research Studies." Retrieved November 13 (1999): 2009.

${ }^{30}$ Cabrera, Alberto F, Amaury Nora, and Maria B Castaneda. "College Persistence: Structural Equations Modeling Test of an Integrated Model of Student Retention." Journal of Higher Education (1993): 123-39.

${ }^{31}$ Polinsky, T.L. "Understanding Student Retention through a Look at Student Goals, Intentions, and

Behavior." Journal of College Student Retention: Research, Theory and Practice 4, no. 4 (2003): $361-76$.

${ }^{32}$ Weng, F., F. Cheong, and C. Cheong. "It Education in Taiwan: Relationship between Self-Efficacy and Academic Integration among Students." (2009).

${ }^{33}$ Bandura, A. Self-Efficacy: The Exercise of Control. (New York: Freeman, 1997), 3

${ }^{34}$ Van der Bijl, Jaap J, and Lillie M Shortridge-Baggett. "The Theory and Measurement of the Self-Efficacy

Construct." Research and Theory for Nursing Practice 15, No. 3 (2001): 189-207.

${ }^{35}$ Porter, S. R., \& Swing, R. L. (2006). Understanding how first-year seminars affect persistence. Research in higher education, 47(1), 89-109.

${ }^{36}$ Luszczynska, A., Gutiérrez-Doña, B., \& Schwarzer, R. (2005). General self-efficacy in various domains of human functioning: Evidence from five countries. International Journal of Psychology, 40(2), 80-89.

${ }^{37}$ Bean, J.P. "Nine Themes of College Student Retention." College student retention: Formula for student success (2005): 215-44.

${ }^{38}$ Close, W , and S Solberg. "Predicting Achievement, Distress, and Retention among Lower-Income Latino Youth." Journal of vocational behavior 72 (2008): 11.

${ }^{39}$ Gore, P. A. "Academic Self-Efficacy as a Predictor of College Outcomes: Two Incremental Validity

Studies." Journal of Career Assessment 14 (2006): 24.

${ }^{40}$ Weng, Cheong \& Cheong, op. cit.

${ }^{41}$ Zajacova, Anna, Scott M Lynch, and Thomas J Espenshade. "Self-Efficacy, Stress, and Academic Success in College." Research in higher education 46, No. 6 (2005): 677-706.

${ }^{42}$ Bean, op. cit.

${ }^{43}$ Weng, Cheong \& Cheong, op. cit.

${ }^{44}$ Torres, J, and V Solberg. "Role of Self-Efficacy, Stress, Social Integration and Family Support in Latino

College Student Persistence and Health." Journal of vocational behavior 23 (2001): 14. 
efficacy and academic integration. Thus self-efficacy is important for first year students' retention. $^{45}$

\section{Review of the related researches}

Not a single organized research work related to students' retention in Pakistan is at hand. Few researches have been carried out focusing on factors that affect students' academic performance and satisfaction in different higher education institutes of Pakistan. Academic performance and satisfaction are somewhat related theme because they lead to success and retention.

\section{Self-efficacy and Retention}

Chemers, Hu and Garcia studied the effects of self-efficacy and optimism on academic performance of students, stress, health and institutional commitment. Self-efficacy was found strongly associated to educational performance and institutional commitment that is to retain in the institution. ${ }^{46}$

Bean reported that students interaction with faculty improves students self-efficacy that further improves their institutional commitment and retention. ${ }^{47}$

Gore conducted a research to find out the effect of self-efficacy on academic success. The results indicated that self-efficacy is a significant factor to predict the academic success. $^{48}$

Devonport and Lane studied a relationship between self-efficacy, coping and retention among first year students. Result indicated that self-efficacy is highly significant in predicting retention among first year students. ${ }^{49}$

DeWitz, Woolsey and Walsh investigated the relationship between Frankl's construct of purpose in life, that is retention, and self-efficacy as a predictor of retention. Through regression analysis it was found that self-efficacy is the most significant predictor of retention. $^{50}$

Weng et. al. studied the relationship between academic integration and self-efficacy at public and private institutions of higher education among students of information

\footnotetext{
${ }^{45}$ Potter, A., and A. Parkinson. "First Year at Risk Intervention Pilot Project: An Intervention to Support First Year Students Experiencing Early Assessment Failure." 2010.

${ }^{46}$ Chemers, M.M., L. Hu, and B.F. Garcia. "Academic Self-Efficacy and First Year College Student Performance and Adjustment." Journal of Educational Psychology 93, No. 1 (2001): 55.

${ }^{47}$ Bean, op.cit.

${ }^{48}$ Gore, op.cit.

49 Devonport, T.J., and A.M. Lane. "Relationships between Self-Efficacy, Coping and Student Retention." Social Behavior and Personality: an international journal 34, No. 2 (2006): 127-38.

${ }^{50}$ DeWitz, S Joseph, M Lynn Woolsey, and W Bruce Walsh. "College Student Retention: An Exploration of the Relationship between Self-Efficacy Beliefs and Purpose in Life among College Students." Journal of college student development 50, No. 1 (2009): 19-34.
} 
management and computer science majors. Self-efficacy of the students of public institutions was found to be higher than students of private institutions. ${ }^{51}$

Potter and Parkinson presented the findings of a project to help first-year students develop self-management and problem-solving capabilities. Self-efficacy was observed to be important for freshmen retention. ${ }^{52}$

Wright, Jenkins-Guarnieri, and Murdock investigated the role of self-efficacy, retention and academic success in 401 students of first year at a university. Regression analysis revealed that high self-efficacy is associated to retention and educational success. ${ }^{53}$

\section{Hypothesis}

The primary aim of the present study is to examine the impact of self-efficacy on intent of first year students to continue their studies in public and private sector universities of Karachi.

\section{Methodology}

The present study is the first of its type in Pakistan to explore retention behavior of first year students. The present study employs a survey method to collect the data from 645 students of public and private sector universities in Karachi.

In the present study, the survey method was used as it is the most effective mean to collect information. Self-administered questionnaire was used to collect the data. The questionnaire was completed by the freshmen to collect the demographic information, self-efficacy and intention to retain at the institution.

Freshmen are selected as the main population because literature review has indicated that, the first year experience is extremely important for later success in higher education ${ }^{54,55,56,57,58}$

\footnotetext{
${ }^{51}$ Weng, Cheong and Cheong, op.cit.

${ }^{52}$ Potter and Parkinson, op. cit.

${ }^{53}$ Wright, Stephen L, Michael A Jenkins-Guarnieri, and Jennifer L Murdock. "Career Development among First-Year College Students: College Self-Efficacy, Student Persistence, and Academic Success." Journal of Career Development (2012).

${ }^{54}$ Baker, B.A., A.L. Caison, and A.W. Meade. "Assessing Gender-Related Differential Item Functioning and Predictive Validity with the Institutional Integration Scale." Educational and psychological measurement 67, No. 3 (2007): 545.

${ }^{55}$ Hawley, T.H., and T.A. Harris. "Student Characteristics Related to Persistence for First-Year Community College Students." Journal of College Student Retention: Research, Theory and Practice 7, No. 1 (2005): 11742.

${ }^{56}$ Krause, Kerri-Lee, Robyn Hartley, Richard James, and Craig McInnis. The First Year Experience in Australian Universities: Findings from a Decade of National Studies. Centre for the Study of Higher Education, University of Melbourne Melbourne, 2005.

${ }^{57}$ Otero, R., O. Rivas, and R. Rivera. "Predicting Persistence of Hispanic Students in Their 1st Year of College." Journal of Hispanic Higher Education 6, no. 2 (2007): 163.

${ }^{58}$ Zimitat, C. "Improving Quality of Teaching Is Part of Improving Retention: A Study of First Year Students in an Australian University." (2006).
} 


\section{Universities in Karachi}

Universities and Degree Awarding Institutes (DAIs) in Pakistan are divided into 5 categories; medical, engineering, business/computer science, general, and agriculture universities and DAIs (HEC Pakistan Annual Report, 2014-15).

There are 147 universities/Degree Awarding Institutes (DAIs) in Pakistan, 82 are in public and 65 are in private sector, including 12 new, which have been established and recognized during 2012-13 (see Table 1)

Table1. Total Number of HEC recognized public and private sector universities/degree awarding institutions of Pakistan*

\begin{tabular}{|c|c|c|c|}
\hline Chartered by & $\begin{array}{c}\text { Public } \\
\text { Universities/DAIs }\end{array}$ & $\begin{array}{c}\text { Private } \\
\text { Universities/DAIs }\end{array}$ & Total \\
\hline Federal Govt. & 21 & 6 & 27 \\
\hline Punjab & 19 & 22 & 41 \\
\hline Sindh & 16 & 25 & 41 \\
\hline KP & 17 & 10 & 27 \\
\hline Baluchistan & 5 & 0 & 5 \\
\hline JK & 4 & 2 & 6 \\
\hline A Total & 82 & 65 & 147 \\
\hline
\end{tabular}

1 (figures quoted above are from the list of HEC recognized universities and DAIs available on HEC Pakistan website).

Out of 41 universities in Sindh, 32 universities are in Karachi (8 Public and 24 Private). There is no agricultural university in Karachi. Remaining 4 public sector universities, one from each category, were included in the present study. The only public sector business university in Karachi refused to participate in the research. There is at least one private sector university of each of the above mentioned categories. Four private universities were selected, one from the each category. Three public and 4 private universities made up the final sample of the study.

\subsection{Sample Size}

The following statistical formula was used to calculate the sample size ' $n$ ' of the population.

$$
\begin{gathered}
\mathbf{S}=\mathbf{Z}^{2}(\mathbf{P}(\mathbf{1}-\mathbf{P}))+(\mathbf{P}(\mathbf{1}-\mathbf{P})) \\
\mathbf{e}^{2}
\end{gathered}
$$

Where,

$\mathrm{s}=$ the sample size 
$\mathrm{z}=$ the number relating to the degree of confidence. $95 \%$ confidence is generally used and accepted. The value of $\mathrm{z}$ for $95 \%$ confidence is 1.96 .

$\mathrm{p}=$ an estimate of the proportion of public and private sector university freshmen who will not register for the next term. It was assumed that $30 \%$ public sector students and $40 \%$ private sector students will not retain at their universities and not register for the next term. Value of $\mathrm{p}$ is 0.3 and 0.4 for public and private sector, respectively.

$\mathrm{e}=$ the proportion of error that the researcher is prepared to accept that is $5 \%$ and the value of $\mathrm{e}$ is 0.05 .

The value of 's' was calculated by putting the values in the above formula

$$
s=691
$$

691 was then multiplied by 2 as there are 2 sectors of universities.

Finally the value of $s=1,382$

Total number of freshmen entered in the 7 universities was 8,200 (see Table 2).

Table 2.Total number of freshmen enrolled in each of the selected university*

\begin{tabular}{|c|c|c|c|}
\hline \multirow{2}{*}{ Categories of Universities } & Public Sector & Private Sector & Total \\
\cline { 2 - 4 } & & & \\
\cline { 2 - 4 } & $\mathrm{n}$ & $\mathrm{n}$ & $\mathrm{N}$ \\
\hline Business & $* *$ & 400 & 400 \\
\hline Engineering & 1500 & 1500 & 3000 \\
\hline General & 3000 & 1000 & 4000 \\
\hline Medical & 400 & 400 & 800 \\
\hline Total & 4900 & 3300 & 8200 \\
\hline
\end{tabular}

*All figures quoted above are provided by the universities in the research

**The only public sector business university in Karachi refused to participate A proportionate sample of the total population was drawn from each of the university (see Table 3). 
Table 3. Proportionate sample size selected from each of the university

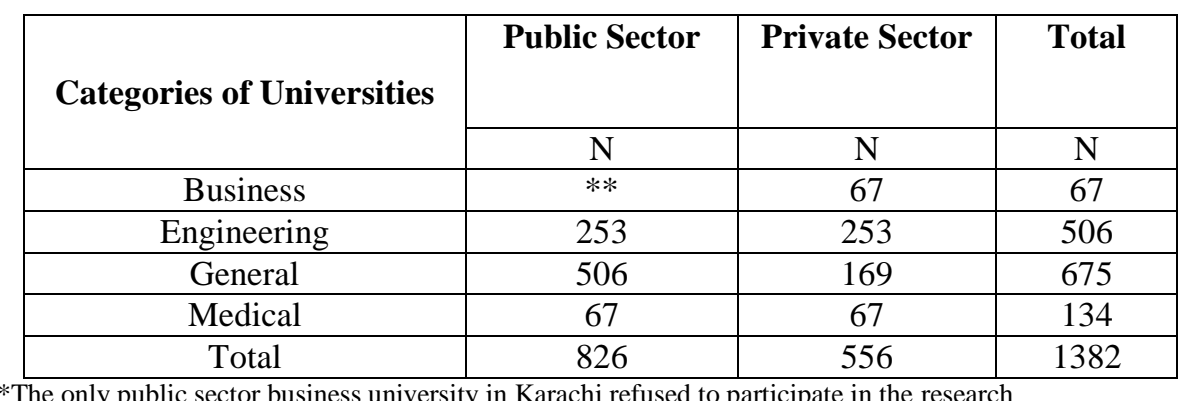

Data was collected with the help of survey questionnaires. The researcher distributed 1,382 surveys to the campuses. Out of 1,382 surveys only 645 were found usable. This made up the total sample of 645 (363 from public sector and 282 from private sector universities). Table 4 shows the demographic summary of the respondents. 
Table 4. Demographic profile of the respondents

\begin{tabular}{|c|c|c|c|c|c|c|}
\hline \multirow{2}{*}{ Demographic profile } & \multicolumn{2}{|c|}{ Public Sector } & \multicolumn{2}{|c|}{ Private Sector } & \multicolumn{2}{|c|}{ Total } \\
\cline { 2 - 7 } & $\mathrm{n}$ & $\%$ & $\mathrm{n}$ & $\%$ & $\mathrm{n}$ & $\%$ \\
\hline Age & & & & & & \\
\hline 18 to 20 years & 286 & 78.78 & 195 & 69.14 & 481 & 74.57 \\
\hline 21 to 23 years & 68 & 18.73 & 75 & 26.59 & 143 & 22.17 \\
\hline 24 years and above & 9 & 2.47 & 12 & 4.25 & 21 & 3.25 \\
\hline Total & 363 & 100 & 282 & 100 & 645 & 100 \\
\hline Gender & & & & & & \\
\hline Male & 118 & 32.5 & 175 & 62.1 & 293 & 45.4 \\
\hline Female & 245 & 67.5 & 107 & 37.9 & 352 & 54.6 \\
\hline Total & 363 & 100 & 282 & 100 & 645 & 100 \\
\hline Employment Status & & & & & & \\
\hline Employed & 18 & 5.0 & 17 & 6.0 & 35 & 5.4 \\
\hline Unemployed & 345 & 95.0 & 265 & 94.0 & 610 & 94.6 \\
\hline Total & 363 & 100 & 282 & 100 & 645 & 100 \\
\hline Marital Status & & & & & & \\
\hline Married & 7 & 1.9 & 13 & 4.6 & 20 & 3.1 \\
\hline Unmarried & 356 & 98.1 & 269 & 95.4 & 625 & 96.9 \\
\hline Total & 363 & 100 & 282 & 100 & 645 & 100 \\
\hline
\end{tabular}

Measures

\section{Self-efficacy}

The Sherer General Self-efficacy Scale was used to measure student's self-efficacy. ${ }^{59}$ It is a 17-item Likert scale (example of items include: "When I make plans, I am certain I can make them work", "I give up easily", "I am a self-reliant person", "I avoid facing difficulties"), the answers ranging from $1=$ Strongly disagree to $5=$ Strongly agree. Sum of item scores reflects general self-efficacy. The scale was developed to measure "a

${ }^{59}$ Sherer, Mark, James E Maddux, Blaise Mercandante, Steven Prentice-Dunn, Beth Jacobs, and Ronald W Rogers. "The Self-Efficacy Scale: Construction and Validation." Psychological reports 51, No. 2 (1982): 66371. 
general set of expectations that the individual carries into new situations". ${ }^{60}$ Overall alpha coefficient ranged from .83 to $.85^{61}$ and the scale is internally consistent ${ }^{62}$

\section{Retention Intention}

The variable was measured by using single item: (1) It is likely I will reenroll at this university next semester. Response option choices ranged from 1 (strongly disagree) to 5 (strongly agree).

\section{Analysis of data}

Quantitative data were analyzed on IBM SPSS Statistics 20. Probit regression test and Spearman's correlation were used to test the relationship between the intention to retain at the university and self-efficacy.

\section{Probit-regression test of the variables}

Probit-regression test has been used to analyze the variables of the present study. The regression analysis between students' intention to stay and self-efficacy showed that the relationship is statistically significant. It proved that self-efficacy does influence intention of students to continue at the current university. The finding was the same for both public and private sector universities (see Table 5).

Table 5. Regression test of self-efficacy and retention intention

\begin{tabular}{|c|c|c|c|c|c|c|c|}
\hline \multirow[b]{2}{*}{ Self-efficacy } & \multirow[b]{2}{*}{ Estimate } & \multirow[b]{2}{*}{ Std. Error } & \multirow[b]{2}{*}{ Wald } & \multirow[b]{2}{*}{ Df } & \multirow[b]{2}{*}{ Sig. } & \multicolumn{2}{|c|}{$\begin{array}{l}95 \% \text { Confidence } \\
\text { Interval }\end{array}$} \\
\hline & & & & & & $\begin{array}{l}\text { Lower } \\
\text { Bound }\end{array}$ & $\begin{array}{l}\text { Upper } \\
\text { Bound }\end{array}$ \\
\hline All Universities & .016 & .004 & 16.840 & 1 & .000 & .009 & .024 \\
\hline $\begin{array}{l}\text { Public } \\
\text { Universities }\end{array}$ & .015 & .006 & $\begin{array}{c}7.10 \\
0\end{array}$ & 1 & $\begin{array}{c}.00 \\
8\end{array}$ & .004 & .026 \\
\hline $\begin{array}{l}\text { Private } \\
\text { Universities }\end{array}$ & .014 & .006 & $\begin{array}{c}5.54 \\
2\end{array}$ & 1 & $\begin{array}{c}.01 \\
9\end{array}$ & .002 & .026 \\
\hline
\end{tabular}

${ }^{60}$ Ibid. p. 664.

${ }^{61}$ Imam, Syed Sohail. "Sherer Et Al. General Self-Efficacy Scale: Dimensionality, Internalconsistency, and Temporalstability." Paper presented at the Proceedings of the Redesigning Pedagogy: Culture, Knowledge and Understanding Conference, Singapore, 2007.

${ }^{62}$ Chen, Gilad, Stanley M Gully, and Dov Eden. "Validation of a New General Self-Efficacy Scale."

Organizational research methods 4, No.1 (2001): 62-83. 


\section{Spearman's Correlation of the variables}

A spearman's correlation test was conducted to determine correlation between the variables. The positive and statistically significant coefficient of self-efficacy and intention $(\mathrm{r}=.16, \mathrm{p}<0.01)$ for overall universities indicated that self-efficacy had an impact on students intention to stay in the same university after one year.

The positive and statistically significant coefficient of self-efficacy $(r=.14, p<0.01)$ for public sector universities indicated that self-efficacy did affect students intention to stay in the same university after one year.

The positive and statistically significant coefficient of self-efficacy $(r=.12, p<0.05)$ for private universities indicated that self-efficacy had an important impact on students intention to stay in the same university after one year.

\section{Conclusion}

The result of the regression test confirmed that self-efficacy was found to have influence on intention to stay in the same university. Findings were the same for both public ( $\mathrm{p}<$ $0.008)$ and private $(p<0.019)$ sectors universities. The results were consistent with the past research that concluded that self-efficacy is a significant factor to determine retention. ${ }^{63,64,65}$ The correlation test also indicated a positive and statistically significant relationship of self-efficacy and intention that confirms that self-efficacy had affected students' intention to remain in the same university after one year. The finding is consistent with the previous researches of Bean (2005), ${ }^{66}$ Devonport and Lane ${ }^{67}$ DeWitz et al ${ }^{68}$ Gore ${ }^{69}$ and Porter and Swing . ${ }^{70}$

Recommendations for future research included:

1. Studying the whole population of the first year students of universities rather than the sample to have a better picture of the retention behavior.

2. Testing the actual retention behavior rather than the intention of students to stay in the institution.

3. Replicating the study on students of the all four years of universities to compare the retention rates across the years.

4. Including self-efficacy as an important variable in the existing retention models.

\footnotetext{
${ }^{63}$ Bean, op.cit.

${ }^{64}$ Porter and Swing, op.cit.

${ }^{65}$ Wright et al, op.cit.

${ }^{66}$ Bean, op.cit.

${ }^{67}$ Devonport and Lane, op.cit.

${ }^{68}$ DeWitz et al, op.cit.

${ }^{69}$ Gore, op. cit.

${ }^{70}$ Porter and Swing, op.cit.
} 


\section{Bibliography}

Abbasi, Muhammad Nauman, Ali Malik, Imran Sharif Chaudhry, and Muhammad Imdadullah. "A Study on Student Satisfaction in Pakistani Universities: The Case of Bahauddin Zakariya University, Pakistan." Asian Social Science 7, no. 7 (2011): 209.

Akram, Muhammad, and Faheem Jehangir Khan. Public Provision of Education and Government Spending in Pakistan. Pakistan Institute of Development Economics, 2007.

Alam Malik, Shahab, Shahzad Hassan, and Muhammad Zahid Iqbal. "Measuring Students' Perceptions and Expectations in Business Schools of Pakistan." Asian Education and Development Studies 1, no. 3 (2012): 222-236.

Arnold, Adrienne. "Retention and Persistence in Postsecondary Education: A Summation of Research Studies." Retrieved November 13, (1999): 2009.

Bandura, A. Self-Efficacy: The Exercise of Control. New York: Freeman, 1997.

Bean, J.P. "Nine Themes of College Student Retention." College student retention: Formula for student success, (2005): 215-244.

Bean, John P, and Barbara S Metzner. "A Conceptual Model of Nontraditional Undergraduate Student Attrition." Review of educational research 55, no. 4 (1985): 485540 .

Benckendorff, Pierre, Lisa Ruhanen, and Noel Scott. "Deconstructing the Student Experience: A Conceptual Framework." Journal of Hospitality and Tourism Management 16, no. 01 (2009): 84-93.

Bers, Trudy H, and Kerry E Smith. "Persistence of Community College Students: The Influence of Student Intent and Academic and Social Integration." Research in higher education 32, no. 5 (1991): 539-556.

Butt, Babar Zaheer, and Kashif U Rehman. "A Study Examining the Students Satisfaction in Higher Education." Procedia Social and Behavioral Sciences 2, (2010): 5446-5450.

Cabrera, Alberto F, Amaury Nora, and Maria B Castaneda. "College Persistence: Structural Equations Modeling Test of an Integrated Model of Student Retention." Journal of Higher Education, (1993): 123-139.

Carter, Deborah Faye. "Key Issues in the Persistence of Underrepresented Minority Students." New Directions for Institutional Research 2006, no. 130 (2006): 33-46.

Chemers, M.M., L. Hu, and B.F. Garcia. "Academic Self-Efficacy and First Year College Student Performance and Adjustment." Journal of Educational Psychology 93, no. 1 (2001): 55. 
Chen, Gilad, Stanley M Gully, and Dov Eden. "Validation of a New General SelfEfficacy Scale." Organizational research methods 4, no. 1 (2001): 62-83.

Close, W, and S Solberg. "Predicting Achievement, Distress, and Retention among Lower-Income Latino Youth." Journal of vocational behavior 72, (2008): 11.

Crosling et al. "Improving Student Retention in Higher Education." Australian Universities' Rivew 51, no. 2 (2009).

DeShields Jr, Oscar W, Ali Kara, and Erdener Kaynak. "Determinants of Business Student Satisfaction and Retention in Higher Education: Applying Herzberg's TwoFactor Theory." International journal of educational management 19, no. 2 (2005): 128139.

Devonport, T.J., and A.M. Lane. "Relationships between Self-Efficacy, Coping and Student Retention." Social Behavior and Personality: an international journal 34, no. 2 (2006): 127-138.

DeWitz, S Joseph, M Lynn Woolsey, and W Bruce Walsh. "College Student Retention: An Exploration of the Relationship between Self-Efficacy Beliefs and Purpose in Life among College Students." Journal of college student development 50, no. 1 (2009): 1934.

Fatima, Anila, and Mohamed Nasr. "Financial Aid as Support for Student Accessibility to Higher Education in Pakistan." International Review of Business Research Papers 6, no. 3 (2010): 205-218.

Gore, P. A. "Academic Self-Efficacy as a Predictor of College Outcomes: Two Incremental Validity Studies." Journal of Career Assessment 14, (2006): 24.

Hagedorn, Linda Serra. "How to Define Retention." College student retention formula for student success, (2005): 90-105.

Huda, Nighat, and Sajida Agha. "Attrition in Medical College: Experience at Ziauddin Medical University in Pakistan." Education for Health. 17, No. 2 (2004): 232-235.

Ijaz, A, SM Irfan, S Shahbaz, M Awan, and M Sabir. "An Empirical Model of Student Satisfaction: Case of Pakistani Public Sector Business Schools." Journal of Quality and Technology Management 7, No. 2 (2011): 91-114.

Imam, Syed Sohail. "Sherer Et Al. General Self-Efficacy Scale: Dimensionality, Internalconsistency, and Temporalstability." In Proceedings of the Redesigning Pedagogy: Culture, Knowledge and Understanding Conference, Singapore, 2007.

Johnson, David R. "Formulating a Conceptual Model of Nontraditional Student Attrition and Persistence in Postsecondary Vocational Education Programs." (1991). 
Luszczynska, A., B. Gutiérrez-Doña, and R. Schwarzer. "General Self-Efficacy in Various Domains of Human Functioning: Evidence from Five Countries." International Journal of Psychology 40, No. 2 (2005): 80-89.

Mutter, Priscilla. "Tinto's Theory of Departure and Community College Student Persistence." Journal of college student development 33, No. 4 (1992): 310-18.

Naseem, Nosheen Rachel. "Structured Peer Mentoring: Enhancing Lifelong Learning in Pakistani Universities." International Perspectives on Education, (2012): 335.

Norton, Jonathan. "Retention and Personal Development: Assessing the Role of Universities in Assisting Students to Navigate Psychological Demands of Higher Education." Journal of the Australia and New Zealand Student Services Association 35, no. 1 (2010): 55-70.

Pascarella, Ernest T, Paul B Duby, and Barbara K Iverson. "A Text and Reconceptualization of a Theoretical Model of College Withdrawal in a Commuter Institution Setting." Sociology of Education, (1983): 88-100.

Polinsky, T.L. "Understanding Student Retention through a Look at Student Goals, Intentions, and Behavior." Journal of College Student Retention: Research, Theory and Practice 4, No. 4 (2003): 361-376.

Porter, Stephen R, and Randy L Swing. "Understanding How First-Year Seminars Affect Persistence." Research in higher education 47, No.1 (2006): 89-109.

Potter, A., and A. Parkinson. "First Year at Risk Intervention Pilot Project: An Intervention to Support First Year Students Experiencing Early Assessment Failure." 2010.

Shah, Najmus Saher. "Predicting Factors That Affect Students'academic Performance by Using Data Mining Techniques." Pakistan Business Review, (2012): 631.

Shahzadi, Erum, and Zahoor Ahmad. "A Study on Academic Performance of University Students." RECENT ADVANCES IN STATISTICS, (2011): 255.

Sherer, Mark, James E Maddux, Blaise Mercandante, Steven Prentice-Dunn, Beth Jacobs, and Ronald W Rogers. "The Self-Efficacy Scale: Construction and Validation." Psychological reports 51, No.2 (1982): 663-671.

Tinto, Vincent. "Student Retention and Graduation: Facing the Truth, Living with the Consequences. Occasional Paper 1." Pell Institute for the Study of Opportunity in Higher Education, (2004).

Torres, J, and V Solberg. "Role of Self-Efficacy, Stress, Social Integration and Family Support in Latino College Student Persistence and Health." Journal of vocational behavior 23, (2001): 14 . 
Ullah, Muhammad Hamid, Muhammad Ajmal, and Fazalur Rahman. "Analysis of Quality Indicators of Higher Education in Pakistan." Ankara, Bilkent University, 2011.

Van der Bijl, Jaap J, and Lillie M Shortridge-Baggett. "The Theory and Measurement of the Self-Efficacy Construct." Research and Theory for Nursing Practice 15, No.3 (2001): 189-207.

Weng, F., F. Cheong, and C. Cheong. "It Education in Taiwan: Relationship between Self-Efficacy and Academic Integration among Students." (2009).

Wright, Stephen L, Michael A Jenkins-Guarnieri, and Jennifer L Murdock. "Career Development among First-Year College Students: College Self-Efficacy, Student Persistence, and Academic Success." Journal of Career Development, (2012).

Zajacova, Anna, Scott M Lynch, and Thomas J Espenshade. "Self-Efficacy, Stress, and Academic Success in College." Research in higher education 46, No.6 (2005): 677-706.

Zhang, Xiaoni, Vijay Raghavan, and Ben Martz. "Investigating Is Student Retention Factors." In Americas Conference on Information Systems (AMCIS). California: Association for Information Systems, 2009. 